\title{
Novel Imaging Biomarkers for Huntington's Disease and Other Hereditary Choreas
}

\author{
Patrik Fazio $^{1,2} \cdot$ Martin Paucar ${ }^{2,3} \cdot$ Per Svenningsson ${ }^{2,3} \cdot$ Andrea Varrone $^{1}$
}

Published online: 5 October 2018

(C) The Author(s) 2018

\begin{abstract}
Purpose of the Review Imaging biomarkers for neurodegenerative disorders are primarily developed with the goal to aid diagnosis, to monitor disease progression, and to assess the efficacy of disease-modifying therapies in support to clinical outcomes that may either show limited sensitivity or need extended time for their evaluation. This article will review the most recent concepts and findings in the field of neuroimaging applied to Huntington's disease and Huntington-like syndromes. Emphasis will be given to the discussion of potential pharmacodynamic biomarkers for clinical trials in Huntington's disease (HD) and of neuroimaging tools that can be used as diagnostic biomarkers in HD-like syndromes.

Recent Findings Several magnetic resonance (MR) and positron emission tomography (PET) molecular imaging tools have been identified as potential pharmacodynamic biomarkers and others are in the pipeline after preclinical validation. MRI and ${ }^{18} \mathrm{~F}$ fluorodeoxyglucose PET can be considered useful supportive diagnostic tools for the differentiation of other HD-like syndromes. Summary New trials in HD have the primary goal to lower mutant huntingtin (mHTT) protein levels in the brain in order to reduce or alter the progression of the disease. MR and PET molecular imaging markers have been developed as tools to monitor disease progression and to evaluate treatment outcomes of disease-modifying trials in HD. These markers could be used alone or in combination for detecting structural and pharmacodynamic changes potentially associated with the lowering of mHTT.
\end{abstract}

Keywords Huntington's disease $\cdot$ Huntington-like $\cdot$ Chorea $\cdot$ Neuroimaging $\cdot$ Pharmacodynamic biomarker $\cdot$ Diagnostic tool

\section{Introduction}

Chorea, from the Greek word for dance, is a rapid and involuntary movement affecting randomly different parts of the body. Chorea has short duration and an irregular pattern. The phenomenology is similar regardless of etiology, and therefore, clinical diagnosis is often challenging [1]. Chorea can be part of either a familial or a sporadic neurodegenerative

This article is part of the Topical Collection on Neuroimaging

Patrik Fazio

patrik.fazio@ki.se

1 Department of Clinical Neuroscience, Centre for Psychiatry

Research, Karolinska Institutet and Stockholm County Council, R5:02 Karolinska University Hospital, SE-171

76 Stockholm, Sweden

2 Department of Neurology, Karolinska University Hospital, Stockholm, Sweden

3 Department of Clinical Neuroscience, Centre for Molecular Medicine, Karolinska Institutet, Stockholm, Sweden disease. Huntington's disease (HD) is the most common cause of chorea associated with a familial neurodegenerative disorder. After the discovery of the causative mutation in 1993 [2], considerable effort has been devoted to understand the underlying pathophysiology and to find disease-modifying treatments. Initially, caudate atrophy was the primary supportive finding for HD diagnosis. Over the years, various neuroimaging modalities have been proposed as HD biomarkers. An ongoing huntingtin lowering trial (IONIS-HTT $\mathrm{Rx}_{\mathrm{x}}$ ) illustrates the need for validated biomarkers for HD. In this review, we describe the existing structural imaging data for HD and HD phenocopies and provide a summary of promising and novel functional neuroimaging tools. Our aim is to illustrate the potential utility of different imaging modalities in clinical investigations of chorea and in clinical trials for HD.

\section{Huntington's Disease}

HD is caused by pathological CAG expansion in huntingtin $(h t t)$. Healthy subjects usually carry 7-12 CAG repeats while the range of intermediate alleles is $27-35$ CAG repeats. 
Penetrance is incomplete for 35-39 CAG repeats and becomes complete with a larger number [3]. The nucleotide expansion size correlates inversely with age of onset and explains up to $60 \%$ of variability in age of onset [3]. CAG age product (CAP) is a useful index, applied in longitudinal studies, to estimate the time to HD phenoconversion [4]. In the majority of cases, the onset occurs during adulthood, whereas manifestations before or at age 20 defines the juvenile form (JHD). The unequivocal presence of motor signs defines a diagnosis of HD [3]. Chorea is the most common motor and characteristic feature of HD but other hyperkinetic manifestations occur in HD (dystonia, myoclonus, and vocalizations). Several voluntary and eye movements are also affected resulting in poor coordination, parkinsonism, motor impersistence, and loss of postural reflexes. Parkinsonism is more common in JHD and in later stages of adult-onset HD. Seizures and myoclonus occur in 35\% of JHD cases [3]. Cognitive decline is progressive and usually precedes HD diagnosis; psychiatric/ behavioral features are variable and include depression, anxiety, apathy, lack of insight, and disinhibition. The course of disease is relentlessly progressive.

\section{Huntington's Disease-Like Syndromes}

An etiological diagnosis is achieved only in a small fraction $(2-3 \%)$ of all chorea cases tested negative for HD [5••, 6•]. Most of these Huntington's disease-like syndromes (HDLs), also called HD phenocopies, are associated with adult-onset. Acquired cases of chorea are beyond the scope of this review and the reader is referred to other articles [7].

Expansions in the $C 9$ orf 72 gene were found to be the most common HDL (frequency $2 \%$ ) in an UK cohort [6•]. Intronic hexanucleotide repeat expansions in C9orf72 are the most common cause of familial amyotrophic lateral sclerosis (ALS) and frontotemporal dementia (FTD), two disease conditions that are often co-morbid $[6 \bullet, 8]$. This mutation is also associated with predominant and variable motor phenotypes (parkinsonism, hyperkinesias, and ataxia) even within the same family [9].

Mutations in prion protein gene (PRNP) cause inherited prion diseases (IPD) which represent up to $15 \%$ of all prion diseases. IPDs are adult-onset and fatal conditions presenting with rapidly progressive dementia, movement disorders (commonly ataxia and myoclonus) and psychiatric symptoms. Familial Creutzfeldt-Jakob disease (fCJD) is the most frequent IPD followed by Gertsmann-Sträussler-Scheinker syndrome (GSS) [10]. A Swedish family affected by a HD phenocopy was reported in 1998 [11]; despite being called Huntington's disease-like 1 (HDL1), not all the affected subjects had chorea. Its underlying mutation is an insertion of extra 8-OPRI into the PRNP gene [12].

Huntington's disease-like 2 (HDL2) affects patients of African ancestry and is caused by CTG/CAG repeat expansions in the Junctophilin-3 gene (JPH3) [13]. In the USA, HDL 2 constitute $1 \%$ of all HDL case [14]. Clinical characteristics overlap substantially with HD and the diagnosis relies on genetic testing.

Spinocerebellar ataxia type 17 (SCA17), originally described in Japan, is caused by a pathological CAG expansion is in the TATA-box-binding protein gene (TBP) [15]. Age of onset is variable and correlates poorly with size of CAG repeats. The main features are ataxia, dementia, involuntary movements (chorea and dystonia), and psychiatric symptoms; parkinsonism and seizures occur in some cases [16]. Screening of cohorts with different ethnicity have established that SCA17 is the second most common HDL in Western populations $[5 \cdot \bullet, 17]$.

Benign hereditary chorea (BHC) is an early-onset condition presenting with movement disorders, developmental delay, pyramidal symptoms, and non-neurological manifestations such as lung disease and hypothyroidism [18]. The disease is caused by mutations in the Thyroid transcription factor-1 gene (TIFT-1) with brain-lung-thyroid syndrome as the most common phenotype, but isolated chorea has been described as generalized, non-progressive, and paradoxically attenuated by levodopa. Other movement disorders include ataxia, dystonia, tremor, and myoclonus [19, 20]. Mutations in the adenylate cyclase type 5 gene (ADCY5) are associated with familial and sporadic BHC with early-onset and nonprogressive symptoms. Hyperkinesia with marked episodic exacerbations particularly at night and facial twitches are other striking features; delay of motor milestones occurs in the most severe presentations $[21,22]$.

The core neuroacanthocytosis syndromes include choreaacanthocytosis (ChAc) and McLeod syndrome (MLS). Both are adult-onset and common features are progressive huntingtonism, vocalizations, and feeding dystonia. Parkinsonism is common in later disease stages. Cognitive decline, pronounced psychiatric symptoms, epilepsy, neuromuscular manifestations such as myopathy and polyneuropathy, and acanthocytosis are also common [23]. Sudden truncal flexions, head drops, and buckling of the knees characterize ChAc [24]. MLS is rarer than ChAc with 150 known cases [25].

Neuroferritinopathy and aceruloplasminemia are two of the diseases included in the group called neurodegeneration with brain iron accumulation (NBIA). Both are adult-onset and associated with heterozygous respectively biallelic mutations in ferritin light polypeptide (FTL) and C gene [26]. Chorea is the predominant feature in neuroferritinopathy; chorea, ataxia, diabetes, and retinopathy define the core symptoms for aceruloplasminemia [26, 27].

Chorea can be one feature of mixed hereditary ataxias, mainly spinocerebellar ataxia types 1,2 , and 3 (SCA1, SCA2, SCA3), dentatorubral-pallidoluysian atrophy (DRPLA), Friedreich ataxia, ataxia telangiectasia, and ataxias 
with oculomotor apraxia. Chorea is common in paroxysmal dyskinesias and occurs in connection with mitochondrial disorders particularly mitochondrial encephalomyopathy, lactic acidosis, and stroke-like episodes (MELAS) and Leigh syndrome and in neurometabolic conditions (e.g., Lesch-Nyhan syndrome, GLUT1 deficiency, and phenylketonuria) [28].

\section{Magnetic Resonance Imaging}

\section{Structural Volumetric MRI in HD}

Striatal atrophy has been the most consistent, sensitive, and robust finding in HD in several observational studies [29, 30]. The largest of them, PREDICT and TRACK HD, have confirmed that this atrophy preceded phenoconversion by several years and progresses into the manifest disease phase $[31 \bullet$, $32 \bullet \bullet, 33 \bullet \cdot, 34]$. For this reason, striatal atrophy has been proposed as a biomarker for future clinical trials [35]. Striatal atrophy is the result of progressive neuronal death and gliosis with particular vulnerability for medium spiny neurons (MSN) following caudo-rostral and dorso-ventral directions [36]. In addition, PREDICT and TRACK HD studies have revealed that later during the premanifest phase, variable cortical and white matter (corpus callosum, the posterior tracts, and the white matter surrounding the striatum) atrophy becomes evident [37]. On the other hand, atrophy is less pronounced in globus pallidus, thalamus, and hippocampus. Volumes of striatum and gray matter at baseline are predictors of HD diagnosis and loss of striatal volume and degree of cortical atrophy correlate with CAG repeat size [38, 39]. In patients with manifest disease, the pattern of cortical atrophy was found to be topographically selective [40]. Estimates of atrophy correlate with functional, motor, and cognitive decline in different structures [31••]. Recently, a clinical trial demonstrated that creatine slowed down the progression rate of striatal atrophy, but the examined clinical parameters did not change [41], suggesting that there are other factors other than striatal neurodegeneration that are linked to the complex symptomatology.

\section{Structural MRI in Huntington's Disease-Like Syndromes}

Neuroimaging data for $C 9$ orf72 with HD-like phenotype are available only for 4 patients and compatible with generalized atrophy $[6,42,43]$. Several studies on C9orf72 FTD have shown symmetric cortical atrophy in frontal, temporal and parietal lobes, thalamus, cerebellum, and corticospinal tracts $[8,44]$. Similar findings were obtained in a longitudinal study on mutation carriers with ALS, FTD, and combined ALSFTD $[45,46]$. Atrophy in thalamus is a recurrent finding and may be useful to differentiate from sporadic FTD [47, 48].
In HDL1/inherited prion diseases, generalized brain and cerebellar atrophy occurs in both 6-OPRI and 8-OPRI but these findings are not specific [49-51]. This is in contrast to sporadic and variant CJD for which neuroimaging can be a supportive tool for the diagnosis [52].

In HDL 2, there is an inverse correlation between the nucleotide expansion size with age of onset and caudate atrophy. Striatal and generalized atrophy were evident in 19 out of 20 patients [14] and radiologically indistinguishable from HD [13].

In the SCA17, salient neuroimaging features include aspecific cerebellar and cerebral atrophy [16] and in one study hyperintensities in the putamen have been described [53].

In benign hereditary chorea, neuroimaging features are in the majority of cases normal but variable and non-specific abnormalities that include cerebral and cerebellar atrophy, pituitary cysts, and hyperintensities in the pallidum and vermis on T2-weigthed images have been described for the brain-lung-thyroid syndrome [54, 55]. Surprisingly, structural neuroimaging is normal in ADCY5-related dyskinesias $[21,56]$.

Similar to HD, in neuroacanthocytosis syndromes, structural neuroimaging demonstrates both caudate atrophy with dilatation of the anterior horns and variable cortical atrophy [57, 58]. MRI commonly shows T2-weighted signal increase in the striatum along with hippocampal sclerosis and atrophy $[59,60]$. Cerebellar atrophy is a rare feature [61] and basal ganglia iron accumulation has also been reported [62]. In McLeod syndrome, striatal atrophy is progressive and inversely correlated with disease duration [63, 64]; less frequent are white matter hyperintensities [63]. Neuroimaging can be normal in asymptomatic mutation carriers [65].

In neuroferritinopathy and aceruloplasminemia, both brain MRI gradient echo (T2*) and fast spin echo modalities reveal abnormalities highly suggestive of neuroferritinopathy [66]. Progressive iron accumulation has been described in all affected and even in asymptomatic mutation FTL carriers [66]. This deposition is visualized on T2 images as hypointensity in the red nucleus, substantia nigra, putamen, pallidus, thalamus, and cerebral cortex. Later on, tissue damage leads to cavitations in the caudate and putamen [66]. In aceruloplasminemia iron accumulation is evident in the thalamus and caudate nucleus [67]. An overview of the main findings is presented in Table 1.

\section{Diffusion Imaging}

Diffusion imaging techniques measures motion features of water molecules in different tissues (e.g., white/gray matter) [69]. The most relevant clinical application is diffusionweighted imaging (DWI) that allows an early detection of ischemic lesions, a more specific delineation of the infarction core volume in stroke patients [70] and tissue characterization 
Table 1 Summary of morphological abnormalities using MRI for the main forms of familial huntingtonism. Caudate atrophy is similar in HD, HDL2, and neuroacanthocytosis syndromes

\begin{tabular}{|c|c|c|c|}
\hline Disease & Pattern of inheritance & Main findings & References \\
\hline Huntington's disease (HD) & $\mathrm{AD}$ & $\begin{array}{l}\text { Progressive striatal atrophy antedating } \\
\text { phenoconversion for years } \\
\text { Variable degree of atrophy in cortical regions } \\
\text { and white matter evident in the premanifest phase }\end{array}$ & 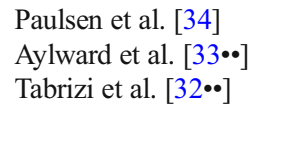 \\
\hline C9orf72-related diseases & $\mathrm{AD}$ & $\begin{array}{l}\text { Generalized atrophy seen } C 9 \text { orf } 72 \text { huntingtonism } \\
\text { but data is limited ( } 6 \text { patients) }\end{array}$ & $\begin{array}{l}\text { Mahoney et al. [8], } \\
\text { Hensman et al. [6•] }\end{array}$ \\
\hline $\begin{array}{l}\text { Huntington's disease-like } 1 \\
\text { (HDL1)/inherited prion diseases (IPD) }\end{array}$ & $\mathrm{AD}$ & Generalized cerebral and cerebellar atrophy & $\begin{array}{l}\text { Xiang et al. [11] } \\
\text { Mead et al. [51] }\end{array}$ \\
\hline Huntington's disease-like 2 (HDL2) & $\mathrm{AD}$ & $\begin{array}{l}\text { Striatal atrophy in all reported cases, variable } \\
\text { degree of cortical atrophy }\end{array}$ & Anderson et al. [14] \\
\hline Spinocerebellar ataxia type 17 (SCA17) & $\mathrm{AD}$ & Generalized cerebral and cerebellar atrophy & $\begin{array}{l}\text { Toyoshima and } \\
\text { Takahashi [16] }\end{array}$ \\
\hline Benign hereditary chorea (BHC) & $\mathrm{AD}$ & $\begin{array}{l}\text { In general normal; cerebral and cerebellar atrophy } \\
\text { and hypoplastic pallidum can occur in BLTa }\end{array}$ & Adam and Jankovic [54] \\
\hline ADCY5-related dyskinesia & $\mathrm{AD}$ & Normal findings & Mencacci et al. [56] \\
\hline \multicolumn{4}{|l|}{ Neuroacanthocytosis } \\
\hline $\begin{array}{l}\text { Chorea-acanthocytosis (ChoAc) } \\
\text { McLeod syndrome (MLS) }\end{array}$ & $\begin{array}{l}\text { AR } \\
\text { XLR }\end{array}$ & $\begin{array}{l}\text { ChoAch: Vast majority displays striatal atrophy, } \\
\text { striatal hyperintensities are common } \\
\text { Striatal atrophy indistinguishable in both ChoAc } \\
\text { and MLS, more prominent in the caudate head } \\
\text { Progressive striatal atrophy demonstrated in MLS }\end{array}$ & $\begin{array}{l}\text { Gradstein et al. [57] } \\
\text { Walterfang et al. [58] } \\
\text { Valko et al. [64] }\end{array}$ \\
\hline \multicolumn{4}{|c|}{ 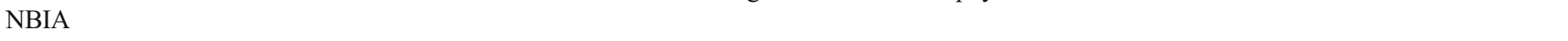 } \\
\hline Neuroferritinopathy & $\mathrm{AD}$ & $\begin{array}{l}\text { T2: Hypondense } \mathrm{BG} \text {, cortex, red nucleus, and } \\
\text { substantia nigra. Cavitations in caudate and putamen }\end{array}$ & McNeill et al. [66] \\
\hline Aceruloplasminemia & $\mathrm{AR}$ & $\begin{array}{l}\text { Iron accumulation in thalamus and caudate, } \\
\text { absence of cavitations }\end{array}$ & Miyajima [68] \\
\hline
\end{tabular}

$A D$ autosomal dominant, $A R$ autosomal recessive, $B G$ basal ganglia, $B L T$ brain-lung-thyroid syndrome, $X L R$ X-linked recessive

of brain tumors [71]. Another informative diffusion-based MR technique is diffusion tensor imaging (DTI) that allows a description of brain tissue microstructures measuring its integrity and white matter abnormalities. This is performed by examining the magnitude of anisotropic diffusion of water molecules assuming a Gaussian distribution of diffusion patterns [72]. Normal white matter fibers show an anisotropic (dependent on direction) diffusivity of water molecules due to the linear structure of axons. Among the measures obtainable from DTI analysis, fractional anisotropy (FA), and mean diffusivity (MD) are the most commonly uses. FA and MD respectively reflect the degree of anisotropy and diffusivity of water molecules at voxel level knowing that both change following microstructural re-arrangement. Changes in FA are conventionally associated with changes of microstructural coherence that might follow pathological processes such loss or gain of tissue organization (axonal density), cellular integrity (e.g., neurodegeneration), and myelination [69]. MD changes are associated with impairment of gray matters microstructure and integrity.

Convincing evidences and description of disease specific DTI patterns are already established in different neurological diseases such as amyotrophic lateral sclerosis [73], Parkinson's disease [74], multiple sclerosis [75], Alzheimer's disease [76], and epilepsy [77].
There are HD-specific DTI patterns that potentially may serve as a surrogate biomarker [35]. On the other hand, different cross-sectional DTI studies in HD highlighted some intrinsic methodological limitations (e.g., small-sample size and varying DTI-based imaging protocols) [78]. Studies that were comparable in design (DTI methods and metrics, regions of interest) suggested a disease-specific pattern characterized by increased FA in the striatum and globus pallidus in manifest HD mutation carriers as compared to control subjects [79-81]. Another consistent pattern has been found in the corpus callosum where a reduction of FA has been described years before the motor symptom onset $[82,83]$. An increase of MD within the basal ganglia, corpus callosum, and thalamus has consistently been described also in premanifest HD mutation carriers with high CAG-associated disease burden score [80, 84, 85]. An unexpected increase of FA in the striatum might reflect a coherent breakdown of different gray and white matter constituents (e.g., microstructure simplification, cytoskeleton degeneration, myelin breakdown, loss of cortical axons) $[79,86]$.

Most of the recent cross-sectional studies in the field were able to show early differences in the premanifest HD mutation group by using multimodal approaches (e.g., gray matters 
metrics) and multivariate statistical models $[84,87]$. The study from the PREDICT-HD Investigators and Coordinators of the Huntington Study Group was able to describe a central-toperipheral and posterior-to-anterior atrophy patterns that spreads from the deep gray matter to deep white matter. Diffusion patterns were characterized by an early increase of MD and FA measurements in the basal ganglia only in premanifest HD mutation carriers with higher CAG-induced disease burden [84].

It is important to notice that diffusion-based MRI techniques are prone to noise due to different factors such as image ghosting, geometric distortions, susceptibility, and movement artifacts. These factors might lead to an increase of withinsubject variability and limit the possibility to use it as longitudinal biomarker to track the disease progression. Test-retest studies have shown low levels of within-subject variability in both early HD patients and healthy controls [88]. However, lower reliabilities of the test-retest for diffusion estimates were detected in the early HD group in cerebellar and brainstem sub-regions and of some gray matters subcortical regions. Accordingly, longitudinal studies were only able to describe specific white matter changes after 18 months in symptomatic HD mutation carriers with a decreased FA in the corpus callosum and middle cingulum [35, 89]. Evidences for longitudinal differences in the diffusion profile for premanifest HD mutation carriers are weaker [90] and available only for premanifest HD mutation carriers with higher disease burden [91]. At the moment, it is difficult to identify a valid and reliable DTI-based MRI biomarker in HD. Particularly difficult is the interpretation of outcome measures in pathological conditions where diffusivitybased measures are overestimated or underestimated by the presence of changes in cellularity, axonal injury, inflammation, and vasogenic edema [92].

\section{Functional Imaging}

\section{Resting-State Functional MRI}

Functional MRI (fMRI)-associated techniques are based on the measurement of fluctuations in brain hemodynamics linked to neuronal activations. The measurable signal relies on blood oxygenation level-dependent (BOLD) contrast that is based by a different signal strength of brain water protons produced by the paramagnetic effects of venous blood de-oxyhemoglobin [93]. The BOLD signal is related to changes in cerebral blood flow, blood volume, and tissue oxygen consumption that typically occurs after neuronal activation [94, 95]. Signal brain maps are thereafter re-constructed indicating the activated brain subregions that are modulated by given cognitive or motor tasks. As opposed to paradigm- or task-based fMRI, resting-state fMRI (rs-fMRI) experiments are performed in a stimulus free environment (i.e., at rest). The principle of rs-fMRI relies on the detection and analysis of spontaneous BOLD signal alterations that are co-activating under passive moments [96]. Anatomically and functionally connected brain regions that demonstrate temporal coherence of those spontaneous fluctuations form a set of defined brain networks: default mode, fronto-parietal, attention, visual, and salience networks [97]. The description of alterations of this "intrinsic neuronal coherence" in physiological and pathological conditions, including neurodegeneration, has provided insights into the functional organization of the brain $[98,99]$. Different well-designed rs-fMRI studies show consistently a decreased intrinsic connectivity pattern across all clinical stages of HD mutation carriers [100]. The earliest reductions were observed in motor, visual, and dorsal attention networks in premanifest $\mathrm{HD}$ mutation carriers as compared to controls followed by a more widespread distribution to subcortical gray matters, including the so called default mode network and occipital areas at early manifest disease stage [101, 102]. Interestingly, implementation of graph theory analysis showed that premanifest HD mutation carriers have a more simplified and non-efficient network structure in the proximity of the diagnosis [103]. However, in a recent cohort of HD gene mutation carriers far from the predicted clinical onset of HD, a comprehensive study assessing sensorymotor brain structures with DTI and rs-fMRI, brain function with neurophysiological examinations, and clinical measures was unable to detect significant differences as compared to healthy controls [104].

Based on rs-fMRI findings, different authors described pattern of increased connectivity in different regions as a part of a compensatory mechanism at early disease stage $[105,106]$.

In early symptomatic HD mutation carriers, connectivity changes in the supplementary motor area and cingulate cortex were associated with motor performances whereas changes in lateral prefrontal networks were associated with cognition when controlling for sub-regional atrophies within the involved nodes [106]. Another study found that in manifest HD mutation carriers the presence of atrophy spatially overlapped with the disrupted intrinsic network unless a voxelwise correction for gray matter volume is performed [107].

The fMRI community is discussing certain limitations with regard to the definition of the resting condition (e.g., eyes open or closed, mental wandering) [108, 109], to the wide variety of analysis methods employed, to the variability of the BOLD signal [110], and to the presence of relevant confounders such as physiological non-brain BOLD signal fluctuations [111]. Despite the caveats, some of the high-level measures obtained with the graph theory-based analysis showed an adequate test-retest variability [112]. If rs-fMRI techniques shall be able to track the disease progression, it is important, beside the aforementioned caveats, that longitudinal studies show detectable changes in the premanifest phase. Different longitudinal studies recently failed to detect 
consistent connectivity changes within the premanifest period of the disease over the course of 1 to 3 years $[113 \cdot, 114]$. A recent cross-sectional and longitudinal study using graph theory-based analysis over 2 years (baseline, year 1, year 2) demonstrated detectable changes for global theory measures only in symptomatic HD mutation carriers which indicated a reduction in the small-world network organization of the brain [103]. Only in the premanifest HD mutation carrier cohort a reduction of hub organization was observed. Across sessions, no significant changes were detected suggesting that those measures were not reliable markers of longitudinal changes in HD [104]. According to recent opinion leaders in the field, it is difficult to identify a valid and reliable rs-fMRI biomarker in HD [100].

\section{Molecular Imaging}

Positron emission tomography (PET) is an in vivo molecular imaging technique able to examine the distribution and concentrations of radiolabelled compounds binding to different molecular targets. Radiolabelled compounds are referred to as radioligands. In recent years $\sim 400$ targets have been evaluated and $\sim 40$ radioligands have been developed and applied to in vivo PET studies in the human brain. For research or clinical purposes, PET has been used to measure the blood flow, glucose metabolism, receptor or transporter densities, enzyme and protein densities and activities. The basic principle of the PET stands on the measurement of emitting annihilation photons that are generated from the decay of positron emitters or isotopes $\left({ }^{18} \mathrm{~F},{ }^{11} \mathrm{C},{ }^{13} \mathrm{~N},{ }^{15} \mathrm{O}\right)$. Positrons emitted in matter lose most of their kinetic energy until an interaction by annihilation with an electron of the surrounding matter (i.e., brain parenchyma) occurs. A PET radioligand is administered intravenously into the blood circulation of the living subject in a condition that can be defined at rest. A dynamic PET study consists in a continuous measurement of the emitted radioactivity (coincidences) in a period of time that varies among different radioligands (commonly 60-90 min) which mirrors the pharmacokinetic behavior of the given molecule in a targeted tissue or volume of interest. Changes in radioactivity concentration in the brain and in the blood are then the objective of quantification to generate physiologically meaningful objective parameters (outcome measures) able to describe different metrics of the biological targets. The biochemical fate of a radioligand and the relative tissue radioactivity concentration are influenced by several factors such as plasma protein binding, permeability of the blood brain barrier, tissue blood flow, rate of the extraction of the tracer from the capillary, binding association and dissociation rates, non-specific tissue binding, and by the presence of radiolabelled metabolites. In the current practice, mathematical models are employed to describe the precise relationship between the in vivo radioligand behavior and a set of parameters of interest in the target tissue. In recent years, efforts are made in order to improve the quantification of relevant biological parameters in pathological situation where structural changes and volume loss are expected. Particularly promising is the combined use of high-resolution MRI images and algorithms for correction of partial volume effects that might enable a better integration of structural and functional information. Different molecular targets may potentially describe the evolution of the underlining neuronal or synaptic loss in relation to the progressive and dynamic changes that are observed during the development of HD pathology in the brain. Therefore, many experts and pharma companies view PET imaging probes as potential surrogate pharmacodynamic biomarkers for HD.

\section{The Role of $\left[{ }^{18} \mathrm{~F}\right] F D G$ in HD and HD-Like Syndromes}

Different PET imaging studies investigating the glucose metabolism in HD mutation carriers were able to define subcortical and cortical metabolic patterns across the entire disease spectrum of the neurodegenerative process with a progressive reduction of subcortical and cortical glucose metabolism [115-117]. The reduction in striatal metabolism is an early feature that can be observed in the premanifest phase of the disease (before the motor onset of the disease). Noteworthy, the striatal reduction of glucose uptake in premanifest HDGECs preceded the beginning of neuronal loss [117, 118]. Longitudinal analysis of premanifest HDGCs using spatial covariance image approaches led to the description of a HD-metabolic progression pattern that consisted in progressive subcortical and cortical hypometabolism in the striatum, thalamus, insula, posterior cingulate gyrus, and prefrontal and occipital cortex associated to a relative hypermetabolism in the cerebellum and pons [119••]. The progressive cortical hypometabolism was correlated with the progression of the cognitive deficits [120]. Unfortunately, no specific patterns were detected for the progression of the psychiatric features of the disease. The utility in the clinical practice of $\left[{ }^{18} \mathrm{~F}\right] \mathrm{FDG}$ PET is limited to rare occasions in which a suspected or confirmed HDGECs present an unclear motor onset. There are also studies that suggested a possible application of $\left[{ }^{18} \mathrm{~F}\right]$ FDG-PET imaging as a tool to predict the time of symptomatic conversion [121].

The $\left[{ }^{18} \mathrm{~F}\right]$ FDG-PET metabolic pattern in other non-HD neurodegenerative and acquired syndromes were recently reviewed by Ehlric and Walker [7]. Metabolic patterns that essentially mimic those observed in HD (a predominant striatal hypometabolism) have been described for different conditions such as in neurochoreacanthocitosis syndromes [60, 122], SCA17 [123], SCA19 [124], and Wilson's disease [125]. According to the literature, the pattern reflects the neurodegenerative nature of those conditions. Of interest, $\left[{ }^{18} \mathrm{~F}\right]$ FDG-PET imaging studies performed in acquired/non- 
degenerative forms of chorea such in the antiphospholipid syndrome [126], polycythemia vera [127], and Sydenham's chorea [128] showed an increased striatal metabolism.

\section{The Role of Dopaminergic Imaging Markers in HD}

Since the major pathological features in HD were traditionally related to the loss of MSNs in the striatum, many PET studies have been focused on post-synaptic dopaminergic receptors. Reduction of dopamine $D_{1}$ and $D_{2}$ receptor availability were reported both in manifest and premanifest HDGECs. Multi receptor PET studies examining D1 receptors with $\left[{ }^{11} \mathrm{C}\right] \mathrm{SCH} 23390$ and $\mathrm{D}_{2}$ receptors with $\left[{ }^{11} \mathrm{C}\right]$ raclopride showed similar impairments of the two receptor systems in manifest and premanifest HDGECs [129-131]. Different PET studies performed with $\left[{ }^{11} \mathrm{C}\right]$ raclopride showed approximately $40-60 \%$ loss of $\mathrm{D}_{2}$ receptors in the striatum of manifest HDGECs and approximately 10-50\% reduction in heterogeneous and small groups of premanifest HDGECs as compared to healthy control subjects $[116,132,133]$. Conflicting results have also been obtained when dopamine $\mathrm{D}_{2}$ receptors availability was measured in extra-striatal areas $[134,135]$. The variability, between studies, regarding the reduction of $\mathrm{D}_{2 / 3}$ receptors found in premanifest HDGECs might represent the consequence of a broad range of CAG repeats and the burden of pathology among the HDGECs examined. In vivo PET studies with presynaptic markers have shown reduction of striatal VMAT2 binding have been reported in manifest HDGECs with the radioligand $\left[{ }^{11} \mathrm{C}\right]$ dihydrotetrabenazine with an estimated reduction of $25 \%$ in the akinetic-rigid motor syb-type [136]. In addition, in a small group of manifest HDGECs, $50 \%$ reduction of DAT binding was described with $\left[{ }^{11} \mathrm{C}\right]$ beta-CIT-PET [129].

\section{The Role of Phosphodiesterase 10A Imaging in HD}

Among many interesting striatal targets, the intracellular phosphodiesterase 10A (PDE10A) enzyme has recently gained attention for the key role in the regulation of striatal signaling and for the presence of suitable pharmaceutical compounds able to modulate it $[137,138]$. PDE10A is highly expressed in MSNs of the striatum, at the confluence of the cortico-striatal glutamatergic and the midbrain dopaminergic pathways, where it encodes the hydrolysis of both cyclic adenosine monophosphate (cAMP) and cyclic guanosine monophosphate (cGMP) [139]. These second messengers are important regulators of molecular signaling in the cortico-striato-thalamic circuit. It has been also reported that PDE10A inhibition improves cortico-basal function in Huntington's disease model with detectable changes with a PDE10A PET radioligand $[140 \bullet \bullet$.

Several studies have already been performed in manifest and premanifest HDGECs with the aim of examining the
PDE10A enzyme [141•]. All PET imaging studies investigating the availability of PDE10A in HDGECs suggested a specific alteration of this protein along with the neurodegenerative process. There are several radioligands currently validated and used in vivo in clinical PET studies: $\left[{ }^{18} \mathrm{~F}\right] J \mathrm{NJ} 42259152$, $\left[{ }^{18} \mathrm{~F}\right] \mathrm{MNI}-659,\left[{ }^{11} \mathrm{C}\right] \mathrm{IMA} 107$, and $\left[{ }^{11} \mathrm{C}\right] \mathrm{Lu}$ AE92686. The work of Ahmad et al. [142] was the first study showing a dramatic reduction (after PVE correction) of the enzyme in five manifest HDGECs compared to 11 healthy controls that were not age-matched $(70 \%$ in the caudate and $65 \%$ in the putamen). In the first cross-sectional study employing a fully validated PDE10 radioligand $\left[{ }^{18} \mathrm{~F}\right] \mathrm{MNI}-659$, Russell et al. showed an average reduction of PDE10A availability of $50 \%$ in three premanifest and eight manifest HDGECs compared to age-matched healthy controls [143]. The same group has recently published a longitudinal study in which eight HDGECs (six manifest and two premanifest) underwent two $\left[{ }^{18} \mathrm{~F}\right] \mathrm{MNI}-659$ PET measurements 1 year apart. On average, the estimates of annual PDE10A loss were $16.6 \%$ in the caudate, $6.9 \%$ in the putamen, and $5.8 \%$ in the globus pallidus. The outcome measures of this study were not corrected for PVE [144]. More recently, using [ $\left.{ }^{11} \mathrm{C}\right] \mathrm{IMA} 107$ PET, a group of 12 early premanifest HDGECs (approximately 25 years before the predicted onset) showed respectively 25 and 33\% reductions in the striatum and in the globus pallidus compared with age-matched healthy controls. At that "stage" in HDGECs, no evident volumetric changes were detected in the gray and white matter structures as result of a morphometric analysis [145••]. Currently our group, in collaboration with the CHDI foundation, has completed a cross-sectional and longitudinal PET study (ClinicalTrials Identifier: NCT02061722) in a large cohort of HD mutation carriers with the intention of measuring PDE10A in relation to $\mathrm{D}_{2}$ receptors across all different disease stages bearing in mind in the study design the necessity to develop a pharmacodynamic biomarker. Preliminary analysis of the results suggests a progressive decrease of PDE10A binding across all stages that goes beyond the $\mathrm{D}_{2}$ receptor and striatal volume loss. The data for this study has been already presented to international conferences [146, 147] (Fig. 1).

\section{Other PET Molecular Imaging Markers}

In humans, other striatal markers, such as adenosine-1, GABA-A, and opioid receptors, have been examined with PET and found to be decreased in HD subjects [148]. The accumulation of mutant huntingtin protein (mHTT) is associated to downregulation of several molecular imaging markers that are expressed not only in the basal ganglia but also in cortical regions. PET imaging studies have demonstrated loss of cannabinoid-1 receptors in animal models of HD and in manifest HD patients [149-151]. Further studies across different stages of the disease are needed to examine whether these 


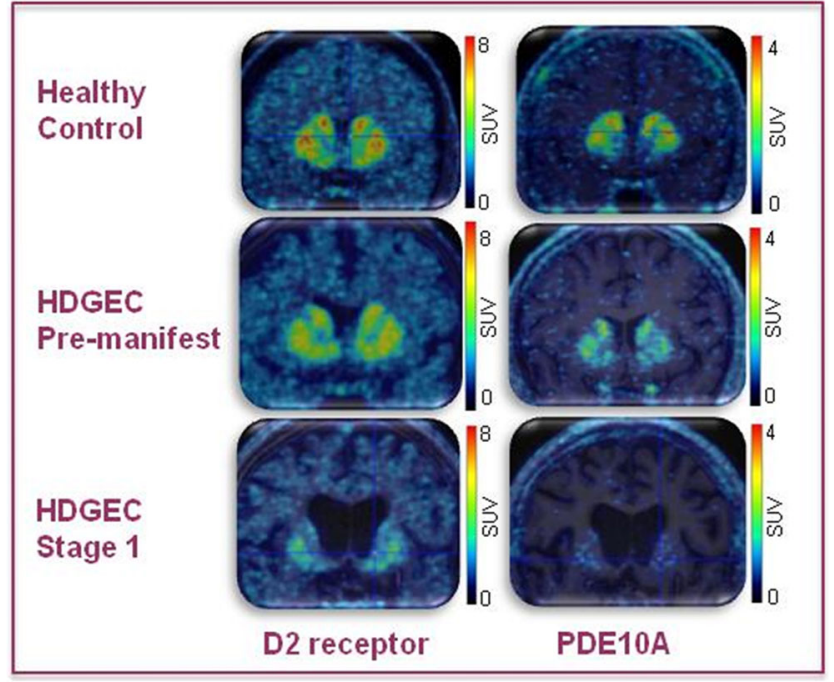

Fig. 1 Representative standardized uptake values (SUV) PET images (D2 receptors and PDE10A enzyme) depicting coronal brain section at the level of basal ganglia for HD mutation carriers at different stages of the disease overlaid on top of individual MRI image

targets can be used as pharmacodynamic biomarkers for clinical trials in HD aimed at lowering mHTT.

\section{Conclusion}

Major efforts are currently underway to identify treatment strategies that could slow down or stop the natural course of the neurodegenerative process at different levels (e.g., delivery of neurotrophic factors, activation of neuronal stem cells, autophagy, and mitochondrial function normalization). Different approaches are in the pipeline at different stages of preclinical or clinical development but currently antisense oligonucleotides (ASOs) and other RNAi-based reagents are the most promising strategies to suppress mHTT message and protein [152]. The antisense oligonucleotides delivered intrathecally has already passed the phase II trials. The ideal biomarker should be able to either measure directly the mHTT strains in the brain or detect pharmacodynamic changes associated to mHTT load. The accumulation and the role of the different mHTT strains is still unclear; therefore, a wider approach with different dedicated molecular target is mandatory at this stage. In the list of imaging biomarker presented in this review striatal volume changes and PDE10A imaging have demonstrated the capability to follow and match the HD pathological process in the basal ganglia. Currently, efforts are made to develop and validate HTT-lowering pharmacodynamic biomarkers that are linked with the amount of accumulated of mHTT in the brain. Finally, efforts are in place to enter in the clinical development a PET radioligand that targets mHTT with assessment in healthy volunteers followed by a cross-sectional study in HD mutation carriers at different stages [153].

\section{Compliance with Ethical Standards}

Conflict of Interest Andrea Varrone reports grants from CHDI Foundation, during the conduct of the study. Per Svenningsson reports grants from Stockholm City Council, grants from Knut och Alice Wallenberg Stiftelse, during the conduct of the study; personal fees from AbbVie, outside the submitted work. Patrik Fazio and Martin Paucar each declare no potential conflict of interest.

Human and Animal Rights and Informed Consent This article does not contain any studies with human or animal subjects performed by any of the authors.

Open Access This article is distributed under the terms of the Creative Commons Attribution 4.0 International License (http:// creativecommons.org/licenses/by/4.0/), which permits unrestricted use, distribution, and reproduction in any medium, provided you give appropriate credit to the original author(s) and the source, provide a link to the Creative Commons license, and indicate if changes were made.

\section{References}

Papers of particular interest, published recently, have been highlighted as:

- Of importance

•• Of major importance

1. Walker, R.H. Differential diagnosis of chorea. Curr Neurol Neurosci Rep. 2011;11:385. https://doi.org/10.1007/s11910-0110202-2.

2. MacDonald ME, Ambrose CM, Duyao MP, Myers RH, Lin C, Srinidhi L, et al. A novel gene containing a trinucleotide repeat that is expanded and unstable on Huntington's disease chromosomes. Cell. 1993;72(6):971-983. https://doi.org/10.1016/00928674(93)90585-E.

3. Bates G, Tabrizi S, Jones L. Huntington's disease, no. 64. USA: Oxford University Press; 2014.

4. Penney JB, Vonsattel JP, MacDonald ME, Gusella JF, Myers RH. CAG repeat number governs the development rate of pathology in Huntington's disease. Ann Neurol. 1997;41(5):689-92.

5.• Wild EJ, Mudanohwo EE, Sweeney MG, Schneider SA, Beck J, Bhatia KP, et al. Huntington's disease phenocopies are clinically and genetically heterogeneous. Mov Disord. 2008;23(5):716-20 A comprehensive clinically oriented discussion on possible HD phenocopies.

6. Hensman Moss DJ, Poulter M, Beck J, Hehir J, Polke JM, Campbell T, et al. C9orf72 expansions are the most common genetic cause of Huntington disease phenocopies. Neurology. 2014;82(4):292-9 This study extends the known phenotype of the C9orf72 expansion as the most common HD phenocopies.

7. Ehrlich DJ, Walker RH. Functional neuroimaging and chorea: a systematic review. J Clin Mov Disord. 2017;4(1):8.

8. Mahoney CJ, Beck J, Rohrer JD, Lashley T, Mok K, Shakespeare $\mathrm{T}$, et al. Frontotemporal dementia with the C9ORF72 hexanucleotide repeat expansion: clinical, neuroanatomical and neuropathological features. Brain. 2012;135(Pt 3):736-50.

9. Beck J, Poulter M, Hensman D, Rohrer JD, Mahoney CJ, Adamson G, et al. Large C9orf72 hexanucleotide repeat expansions are seen in multiple neurodegenerative syndromes and are more frequent than expected in the UK population. Am J Hum Genet. 2013;92(3):345-53. 
10. Brown K, Mastrianni JA. The prion diseases. J Geriatr Psychiatry Neurol. 2010;23(4):277-98.

11. Xiang F, Almqvist EW, Huq M, Lundin A, Hayden MR, Edstrom $\mathrm{L}$, et al. A Huntington disease-like neurodegenerative disorder maps to chromosome 20p. Am J Hum Genet. 1998;63(5):1431-8.

12. Moore RC, Xiang F, Monaghan J, Han D, Zhang Z, Edström L, et al. Huntington disease phenocopy is a familial prion disease. Am J Hum Genet. 2001;69(6):1385-8.

13. Margolis RL, O'Hearn E, Rosenblatt A, Willour V, Holmes SE, Franz ML, et al. A disorder similar to Huntington's disease is associated with a novel CAG repeat expansion. Ann Neurol. 2001;50(6):373-80.

14. Anderson DG, Walker RH, Connor M, Carr J, Margolis RL, Krause A. A systematic review of the Huntington disease-like 2 phenotype. J Huntingtons Dis. 2017;6(1):37-46.

15. Koide R, Kobayashi S, Shimohata T, Ikeuchi T, Maruyama M, Saito M, et al. A neurological disease caused by an expanded CAG trinucleotide repeat in the TATA-binding protein gene: a new polyglutamine disease? Hum Mol Genet. 1999;8(11):204753.

16. Toyoshima Y, Takahashi H. Spinocerebellar ataxia type 17 (SCA17). Adv Exp Med Biol. 2018;1049:219-31.

17. Bauer P, Laccone F, Rolfs A, Wüllner U, Bösch S, Peters H, et al. Trinucleotide repeat expansion in SCA17/TBP in white patients with Huntington's disease-like phenotype. J Med Genet. 2004;41(3):230-2.

18. Breedveld GJ, van Dongen JWF, Danesino C, Guala A, Percy AK, Dure LS, et al. Mutations in TITF-1 are associated with benign hereditary chorea. Hum Mol Genet. 2002;11(8):971-9.

19. Willemsen MAAP, Breedveld GJ, Wouda S, Otten BJ, Yntema JL, Lammens M, et al. Brain-thyroid-lung syndrome: a patient with a severe multi-system disorder due to a de novo mutation in the thyroid transcription factor 1 gene. Eur J Pediatr. 2005;164(1):28-30.

20. Carré A, Szinnai G, Castanet M, Sura-Trueba S, Tron E, BroutinL'Hermite I, et al. Five new TTF1/NKX2.1 mutations in brainlung-thyroid syndrome: rescue by PAX8 synergism in one case. Hum Mol Genet. 2009;18(12):2266-76.

21. Chen Y-Z, Matsushita MM, Robertson P, Rieder M, Girirajan S, Antonacci F, et al. Autosomal dominant familial dyskinesia and facial myokymia: single exome sequencing identifies a mutation in adenylyl cyclase 5. Arch Neurol. 2012;69(5):630-5.

22. Chang FCF, Westenberger A, Dale RC, Smith M, Pall HS, PerezDueñas B, et al. Phenotypic insights into ADCY5-associated disease. Mov Disord. 2016;31(7):1033-40.

23. R. H. Walker, H. H. Jung, C. Dobson-Stone, L. Rampoldi, A. Sano, F. Tison, and A. Danek, Neurologic phenotypes associated with acanthocytosis, Neurology, vol. 68, 2007.

24. Bader B, Walker RH, Vogel M, Prosiegel M, McIntosh J and Danek A. Tongue protrusion and feeding dystonia: a hallmark of chorea-acanthocytosis, Mov Disord. 2010;15;25(1):127-9. https://doi.org/10.1002/mds.22863.

25. Peikert K, Danek A, Hermann A.Current state of knowledge in Chorea-Acanthocytosis as core Neuroacanthocytosis syndrome. Eur J Med Genet. 2017. https://doi.org/10.1016/j.ejmg.2017.12. 007

26. McNeill A, Chinnery PF. Neurodegeneration with brain iron accumulation. Handb Clin Neurol. 2011;100:161-72.

27. Hayflick SJ, Kurian MA, Hogarth P. Chapter 19-neurodegeneration with brain iron accumulation. In: Geschwind DH, Paulson HL, Klein C, editors. Neurogenetics, Part I, vol. 147. New York: Elsevier; 2018. p. 293-305.

28. Mencacci NE, Carecchio M. Recent advances in genetics of chorea. Curr Opin Neurol. 2016;29(4):486-95.
29. Aylward EH. Magnetic resonance imaging striatal volumes: a biomarker for clinical trials in Huntington's disease. Mov Disord. 2014;29(11):1429-33.

30. Ross CA, Aylward EH, Wild EJ, Langbehn DR, Long JD, Warner $\mathrm{JH}$, et al. Huntington disease: natural history, biomarkers and prospects for therapeutics. Nat Rev Neurol. 2014;10(4):204-16.

31.• Tabrizi SJ, Langbehn DR, Leavitt BR, Roos RAC, Durr A, Craufurd D, et al. Biological and clinical manifestations of Huntington's disease in the longitudinal TRACK-HD study: cross-sectional analysis of baseline data. Lancet Neurol. 2009;8(9):791-801 This multicenter study included data from 366 individuals (123 controls, 120 premanifest (pre-HD) individuals, and 123 patients with early HD) with an extensive battery of assessments (multi-site 3T MRI, clinical, cognitive, quantitative motor, oculomotor, and neuropsychiatric measures). The results provided robust evidences of significant changes in grey and white matter brain volumes and impairment in oculomotor tasks and cognitive and neuropsychiatric dysfunction in premanifest and early symptomatic HD gene carriers with normal motor scores.

32.• Tabrizi SJ, Scahill RI, Durr A, Roos RA, Leavitt BR, Jones R, et al. Biological and clinical changes in premanifest and early stage Huntington's disease in the TRACK-HD study: the 12month longitudinal analysis. Lancet Neurol. 2011;10(1):31-42 The longitudinal part of the TRACK-HD study that included 116 pre-HD individuals, 114 early HD patients, and 115 people that completed follow-up. After 12 months quantitative imaging showed the greatest differentiation across the spectrum of disease and functional measures were sensitive in early $\mathrm{HD}$, with cognitive and quantitative motor impairment that were detectable in presymptomatic HD gene mutation carriers.

33.• Aylward EH, Nopoulos PC, Ross CA, Langbehn DR, Pierson RK, Mills JA, et al. Longitudinal change in regional brain volumes in prodromal Huntington disease. J Neurol Neurosurg Psychiatry. 2011;82(4):405-10 This study was designed to examine the potential utility of structural MRI measures as outcome measures for clinical trials. Data are presented from 211 prodromal individuals and 60 controls, scanned both at baseline and at the 2-year follow-up. The obtained results suggested that presymptomatic HD mutation carriers with an expected motor onset within 15 years showed a larger disease-related atrophy in white matter than in striatum if the age-related changes were taken into account.

34. Paulsen JS, Langbehn DR, Stout JC, Aylward E, Ross CA, Nance $\mathrm{M}$, et al. Detection of Huntington's disease decades before diagnosis: the predict-HD study. J Neurol Neurosurg Psychiatry. Aug. 2008;79(8):874-80.

35. Georgiou-Karistianis N, Scahill R, Tabrizi SJ, Squitieri F, Aylward E. Structural MRI in Huntington's disease and recommendations for its potential use in clinical trials. Neurosci Biobehav Rev. 2013;37(3):480-90.

36. Vonsattel JPG, Keller C, and Cortes Ramirez EP. Huntington's disease - neuropathology. Handb Clin Neurol. 2011;100:83-100. https://doi.org/10.1016/B978-0-444-52014-2.00004-5.

37. Hobbs NZ, Pedrick AV, Say MJ, Frost C, Dar Santos R, Coleman $A$, et al. The structural involvement of the cingulate cortex in premanifest and early Huntington's disease. Mov Disord. 2011;26(9):1684-90.

38. Rosas HD, Goodman J, Chen YI, Jenkins BG, Kennedy DN, Makris N, et al. Striatal volume loss in HD as measured by MRI and the influence of CAG repeat. Neurology. 2001;57(6):1025-8.

39. Bechtel N, Scahill RI, Rosas HD, Acharya T, van den Bogaard SJA, Jauffret C, et al. Tapping linked to function and structure in premanifest and symptomatic Huntington disease. Neurology. 2010;75(24):2150-60. 
40. Rosas HD, Salat DH, Lee SY, Zaleta AK, Pappu V, Fischl B, et al. Cerebral cortex and the clinical expression of Huntington's disease: complexity and heterogeneity. Brain. 2008;131(Pt 4):105768.

41. Rosas HD, Doros G, Gevorkian S, Malarick K, Reuter M, Coutu J-P, et al. PRECREST: a phase II prevention and biomarker trial of creatine in at-risk Huntington disease. Neurology. 2014;82(10): $850-7$.

42. Koutsis G, Karadima G, Kartanou C, Kladi A, Panas M. C9ORF72 hexanucleotide repeat expansions are a frequent cause of Huntington disease phenocopies in the Greek population. Neurobiol Aging. 2015;36(1):547.e13-6.

43. Kostic VS, Dobricic V, Stankovic I, Ralic V, Stefanova E. C9orf72 expansion as a possible genetic cause of Huntington disease phenocopy syndrome. J Neurol. 2014;261(10):1917-21.

44. Whitwell JL, Weigand SD, Boeve BF, Senjem ML, Gunter JL. Neuroimaging signatures of frontotemporal dementia genetics: C9ORF72, tau, progranulin and sporadics. Brain. 2012;135(3): 794-806.

45. Floeter MK, Bageac D, Danielian LE, Braun LE, Traynor BJ, Kwan JY. Longitudinal imaging in C9orf72 mutation carriers: relationship to phenotype. NeuroImage Clin. 2016;12:1035-43.

46. Rohrer JD, Isaacs AM, Mizielinska S, Mead S, Lashley T, Wray S, et al. C9orf72 expansions in frontotemporal dementia and amyotrophic lateral sclerosis. Lancet Neurol. 2015;14(3):291-301.

47. Schönecker S, Neuhofer C, Otto M, Ludolph A, Kassubek J, Landwehrmeyer B, et al. Atrophy in the thalamus but not cerebellum is specific for C9orf72 FTD and ALS patients - an atlasbased volumetric MRI study. Front Aging Neurosci. 2018;10:45.

48. Sha SJ, Takada LT, Rankin KP, Yokoyama JS, Rutherford NJ, Fong JC, et al. Frontotemporal dementia due to C9ORF72 mutations: clinical and imaging features. Neurology. 2012;79(10): 1002-11.

49. Paucar M, Xiang F, Moore R, Walker R, Winnberg E, Svenningsson P. Genotype-phenotype analysis in inherited prion disease with eight octapeptide repeat insertional mutation. Prion. 2013;7(6):501-10.

50. Vita E, Ridgway GR, White MJ, Porter MC, Caine D, Rudge P. De neuroanatomical correlates of prion disease progression-a $3 \mathrm{~T}$ longitudinal voxel-based morphometry study. Neuroimage Clin. 2016;13:89-96

51. Mead S, Poulter M, Beck J, Webb TEF, Campbell TA, Linehan $\mathrm{JM}$, et al. Inherited prion disease with six octapeptide repeat insertional mutation - molecular analysis of phenotypic heterogeneity. Brain. 2006;129(Pt 9):2297-317.

52. Macfarlane RG, Wroe SJ, Collinge J, Yousry TA, Jäger HR. Neuroimaging findings in human prion disease. J Neurol Neurosurg Psychiatry. 2007;78(7):664-70.

53. Loy CT, Sweeney MG, Davis MB, Wills AJ, Sawle GV, Lees AJ, et al. Spinocerebellar ataxia type 17: extension of phenotype with putaminal rim hyperintensity on magnetic resonance imaging. Mov Disord. 20(11):1521-3.

54. Adam OR, Jankovic J. Benign hereditary chorea. In: Walker RH, editor. The differential diagnosis of chorea. Oxford: Oxford University Press; 2011.

55. do Carmo Costa M, Costa C, Silva AP, Evangelista P, Santos L, Ferro A, et al. Nonsense mutation in TITF1 in a Portuguese family with benign hereditary chorea. Neurogenetics. 2005;6(4):209-15.

56. Mencacci NE, Erro R, Wiethoff S, Hersheson J, Ryten M. ADCY5 mutations are another cause of benign hereditary chorea. Neurology. 2015;85(1):80-8.

57. Gradstein L, Danek A, Grafman J, Fitzgibbon EJ. Eye movements in chorea-acanthocytosis. Invest Ophthalmol Vis Sci. 2005;46(6): 1979-87.
58. Walterfang M, Looi JCL, Styner M, Walker RH, Danek A, Niethammer M, et al. Shape alterations in the striatum in choreaacanthocytosis. Psychiatry Res. 2011;192(1):29-36.

59. Scheid R, Bader B, Ott DV, Merkenschlager A, Danek A. Development of mesial temporal lobe epilepsy in choreaacanthocytosis. Neurology. 2009;73(17):1419-22.

60. Tanaka M, Hirai S, Kondo S, Sun X, Nakagawa T, Tanaka S, et al. Cerebral hypoperfusion and hypometabolism with altered striatal signal intensity in chorea-acanthocytosis: a combined PET and MRI study. Mov Disord. 1998;13(1):100-7.

61. Katsube T, Shimono T, Ashikaga R, Hosono M, Kitagaki H, Murakami T. Demonstration of cerebellar atrophy in neuroacanthocytosis of 2 siblings. AJNR Am J Neuroradiol. 2009;30(2):386-8

62. Lee J-H, Lee S-M, Baik S-K. Demonstration of striatopallidal iron deposition in chorea-acanthocytosis by susceptibility-weighted imaging. J Neurol. 2011;258(2):321-2.

63. Danek A, Rubio JP, Rampoldi L, HoM, Dobson-Stone C, Tison F, Symmans WA, Oechsner M, KalckreuthW and Watt JM. McLeod neuroacanthocytosis: genotype and phenotype. Ann Neurol. 2001; 50(6):755-64.

64. Valko PO, Hänggi J, Meyer M, Jung HH. Evolution of striatal degeneration in McLeod syndrome. Eur J Neurol. 2010;17(4): 612-8.

65. Jung HH, Hergersberg M, Vogt M, Pahnke J, Treyer V, Röthlisberger B, Kollias SS, Russo D, Frey BM. McLeod phenotype associated with a XK missense mutation without hematologic, neuromuscular, or cerebral involvement. Transfus. 2003;43(7): 928-38.

66. McNeill A, Birchall D, Hayflick SJ, Gregory A, Schenk JF, Zimmerman EA, et al. T2* and FSE MRI distinguishes four subtypes of neurodegeneration with brain iron accumulation. Neurology. 2008;70(18):1614-9.

67. Fujita K, Osaki Y, Harada M, Kono S, Miyajima H, Izumi Y, et al. Brain and liver iron accumulation in aceruloplasminemia. Neurology. 2013;81(24):2145 LP-2146.

68. Miyajima H. Aceruloplasminemia. 2003 Aug 12 [Updated 2015 Nov 5]. In: Adam MP, Ardinger HH, Pagon RA, et al., editors. GeneReviews®. Seattle (WA): University of Washington; 19932018. Available from: https://www.ncbi.nlm.nih.gov/books/ NBK1493/.

69. Le Bihan D. Looking into the functional archetecture of the brain with diffusion MRI. Nat Rev Neurosci. 2003;4(6):469-80.

70. Chalela JA, Kidwell CS, Nentwich LM, Luby M, Butman JA, Demchuk AM, et al. Magnetic resonance imaging and computed tomography in emergency assessment of patients with suspected acute stroke: a prospective comparison. Lancet (London, England). 2007;369(9558):293-8.

71. U.S. Department of Health and Human Services Food and Drug and A. for D. E. and R. (CEDR). Guidance for industry: qualification process for drug development tools. 2014.

72. Viallon M, Cuvinciuc V, Delattre B, Merlini L, Barnaure-Nachbar I, Toso-Patel S, et al. State-of-the-art MRI techniques in neuroradiology: principles, pitfalls, and clinical applications. Neuroradiology. 2015;57(5):441-67.

73. Geraldo AF, Pereira J, Nunes P, Reimao S, Sousa R, CasteloBranco $\mathrm{M}$, et al. Beyond fractional anisotropy in amyotrophic lateral sclerosis: the value of mean, axial, and radial diffusivity and its correlation with electrophysiological conductivity changes. Neuroradiology. 2018;60(5):505-15.

74. Cochrane CJ, Ebmeier KP. Diffusion tensor imaging in parkinsonian syndromes: a systematic review and meta-analysis. Neurology. 2013;80(9):857-64.

75. Klistorner A, Wang C, Fofanova V, Barnett MH, Yiannikas C, Parratt J, et al. Diffusivity in multiple sclerosis lesions: at the cutting edge? NeuroImage Clin. 2016;12:219-26. 
76. Lindemer ER, Salat DH, Smith EE, Nguyen K, Fischl B, Greve DN. White matter signal abnormality quality differentiates mild cognitive impairment that converts to Alzheimer's disease from nonconverters. Neurobiol Aging. 2015;36(9):2447-57.

77. Deleo F, Thom M, Concha L, Bernasconi A, Bernhardt BC, Bernasconi N. Histological and MRI markers of white matter damage in focal epilepsy. Epilepsy Res. 2018;140(November 2017):29-38.

78. Liu W, Yang J, Burgunder JM, Cheng B, Shang H. Diffusion imaging studies of Huntington's disease: a meta-analysis. Park Relat Disord. 2016;32:94-101.

79. Douaud G, Behrens TE, Poupon C, Cointepas Y, Jbabdi S, Gaura $\mathrm{V}$, et al. In vivo evidence for the selective subcortical degeneration in Huntington's disease. Neuroimage. 2009;46(4):958-66.

80. Sánchez-Castañeda C, Cherubini A, Elifani F, Péran P, Orobello S, Capelli G, et al. Seeking Huntington disease biomarkers by multimodal, cross-sectional basal ganglia imaging. Hum Brain Mapp. 2013;34(7):1625-35.

81. Rosas HD, Tuch DS, Hevelone ND, Zaleta AK, Vangel M, Hersch $\mathrm{SM}$, et al. Diffusion tensor imaging in presymptomatic and early Huntington's disease: selective white matter pathology and its relationship to clinical measures. Mov Disord. 2006;21(9):131725.

82. Rosas HD, Lee SY, Bender AC, Zaleta AK, Vangel M, Yu P, et al. Altered white matter microstructure in the corpus callosum in Huntington's disease: implications for cortical 'disconnection,'. Neuroimage. 2010;49(4):2995-3004.

83. Crawford HE, Hobbs NZ, Keogh R, Langbehn DR, Frost C, Johnson $\mathrm{H}$, et al. Corpus callosal atrophy in premanifest and early Huntington's disease. J Huntingtons Dis. 2013;2(4):517-26.

84. Faria AV, Ratnanather JT, Tward DJ, Lee DS, Van Den Noort F, $\mathrm{Wu} \mathrm{D}$, et al. Linking white matter and deep gray matter alterations in premanifest Huntington disease. NeuroImage Clin. 2016;11: 450-60.

85. Seppi K, Schocke MFH, Mair KJ, Esterhammer R, WeirichSchwaiger H, Utermann B, et al. Diffusion-weighted imaging in Huntington's disease. Mov Disord. 2006;21(7):1043-7.

86. Pierpaoli C, Basser PJ. Toward a quantitative assessment of diffusion anisotropy. Magn Reson Med. 1996;36(6. New York):893906.

87. Wu D, Faria AV, Younes L, Mori S, Brown T, Johnson H, et al. Mapping the order and pattern of brain structural MRI changes using change-point analysis in premanifest Huntington's disease. Hum Brain Mapp. 2017;38(10):5035-50.

88. Cole JH, Farmer RE, Rees EM, Johnson HJ, Frost C, Scahill RI, et al. Test-retest reliability of diffusion tensor imaging in Huntington's disease. PLoS Curr. 2014;6: ecurrents.hd.f19ef63fff962f5cd9c0e88f4844f43b.

89. Poudel GR, Stout JC, Domínguez DJF, Churchyard A, Chua P, Egan GF, et al. Longitudinal change in white matter microstructure in Huntington's disease: the IMAGE-HD study. Neurobiol Dis. 2015;74(1):406-12.

90. Odish OFF, Leemans A, Reijntjes RHAM, van den Bogaard SJA, Dumas EM, Wolterbeek R, et al. Microstructural brain abnormalities in Huntington's disease: a two-year follow-up. Hum Brain Mapp. 2015;36(6):2061-74.

91. Shaffer JJ, Ghayoor A, Long JD, Kim REY, Lourens S, O’Donnell $\mathrm{LJ}$, et al. Longitudinal diffusion changes in prodromal and early HD: evidence of white-matter tract deterioration. Hum Brain Mapp. 2017;38(3):1460-77.

92. Anderson AW, Xie J, Pizzonia J, Bronen RA, Spencer DD, Gore JC. Effects of cell volume fraction changes on apparent diffusion in human cells. Magn Reson Imaging. 2000;18(6):689-95.

93. Ogawa S, Menon RS, Tank DW, Kim SG, Merkle H, Ellermann $\mathrm{JM}$, et al. Functional brain mapping by blood oxygenation leveldependent contrast magnetic resonance imaging. A comparison of signal characteristics with a biophysical model. Biophys J. 1993;64(3):803-12.

94. Logothetis NK. The neural basis of the blood-oxygen-leveldependent functional magnetic resonance imaging signal. Philos Trans R Soc Lond Ser B Biol Sci. 2002;357(1424):1003-37.

95. Nir Y, Dinstein I, Malach R, Heeger DJ. BOLD and spiking activity. Nat Neurosci. 2008;11(5):523-4 author reply 524.

96. Biswal B, Yetkin FZ, Haughton VM, Hyde JS. Functional connectivity in the motor cortex of resting human brain using echoplanar MRI. Magn Reson Med. 1995;34(4):537-41.

97. Buckner RL. The serendipitous discovery of the brain's default network. Neuroimage. 2012;62(2):1137-45.

98. Zhang D, Raichle ME. Disease and the brain's dark energy. Nat Rev Neurol. 2010;6(1):15-28.

99. Pievani M, Filippini N, van den Heuvel MP, Cappa SF, Frisoni GB. Brain connectivity in neurodegenerative diseases - from phenotype to proteinopathy. Nat Rev Neurol. 2014;10(11):620-33.

100. Hohenfeld C, Werner CJ, Reetz K. Resting-state connectivity in neurodegenerative disorders: is there potential for an imaging biomarker? NeuroImage Clin. 2018;18(March):849-70.

101. Dumas EM, van den Bogaard SJA, Hart EP, Soeter RP, van Buchem MA, van der Grond J, et al. Reduced functional brain connectivity prior to and after disease onset in Huntington's disease. NeuroImage Clin. 2013;2(1):377-84.

102. Poudel GR, Egan GF, Churchyard A, Chua P, Stout JC, GeorgiouKaristianis N. Abnormal synchrony of resting state networks in premanifest and symptomatic Huntington disease: the IMAGEHD study. J Psychiatry Neurosci. 2014;39(2):87-96.

103. Harrington DL, Rubinov M, Durgerian S, Mourany L, Reece C, Koenig K, et al. Network topology and functional connectivity disturbances precede the onset of Huntington's disease. Brain. 2015;138(8):2332-46.

104. Gargouri F, Messé A, Perlbarg V, Valabregue R, McColgan P, Yahia-Cherif L, et al. Longitudinal changes in functional connectivity of cortico-basal ganglia networks in manifests and premanifest Huntington's disease. Hum Brain Mapp. 2016;37(11):4112-28.

105. Werner CJ, Dogan I, Saß C, Mirzazade S, Schiefer J, Shah NJ, et al. Altered resting-state connectivity in Huntington's disease. Hum Brain Mapp. 2014;35(6):2582-93.

106. Wolf RC, Sambataro F, Vasic N, Depping MS, Thomann PA, Landwehrmeyer GB, et al. Abnormal resting-state connectivity of motor and cognitive networks in early manifest Huntington's disease. Psychol Med. 2014;44(15):3341-56.

107. Quarantelli M, Salvatore E, Delle Acque Giorgio SM, Filla A, Cervo A, Russo CV, et al. Default-mode network changes in Huntington's disease: an integrated MRI study of functional connectivity and morphometry. PLoS One. 2013;8:8.

108. Patriat R, Molloy EK, Meier TB, Kirk GR, Nair VA, Meyerand $\mathrm{ME}$, et al. The effect of resting condition on resting-state fMRI reliability and consistency: a comparison between resting with eyes open, closed, and fixated. Neuroimage. 2013;78:463-73.

109. Mason MF, Norton MI, Van Horn JD, Wegner DM, Grafton ST, Macrae CN. Wandering minds: the default network and stimulusindependent thought. Science. 2007;315(5810):393-5.

110. McGonigle DJ. Test-retest reliability in fMRI: or how I learned to stop worrying and love the variability. Neuroimage. 2012;62(2): 1116-20.

111. Birn RM, Cornejo MD, Molloy EK, Patriat R, Meier TB, Kirk GR, et al. The influence of physiological noise correction on test-retest reliability of resting-state functional connectivity. Brain Connect. 2014;4(7):511-22.

112. Cao H, Plichta MM, Schäfer A, Haddad L, Grimm O, Schneider $\mathrm{M}$, et al. Test-retest reliability of fMRI-based graph theoretical properties during working memory, emotion processing, and resting state. Neuroimage. 2014;84:888-900. 
113. Odish OFF, van den Berg-Huysmans AA, van den Bogaard SJA, Dumas EM, Hart EP, Rombouts SARB, et al. Longitudinal resting state fMRI analysis in healthy controls and premanifest Huntington's disease gene carriers: a three-year follow-up study. Hum Brain Mapp. 2015;36(1):110-9 In this article, a welldesigned longitudinal analysis of the resting-state fMRI (RSfMRI) data revealed no differences in the degree of connectivity change between the groups over a period of 3 years, though a significantly higher rate of striatal atrophy was found in the pre-HD group compared to controls in the same period.

114. Young AB, Penney JB, Starosta-Rubinstein S, Markel DS, Berent S, Giordani B, Ehrenkaufer R, Jewett D, Hichwa R. PET scan investigations of Huntington's disease: cerebral metabolic correlates of neurological features and functional decline. Ann Neurol 1986;20(3):296-303.

115. Young AB, Penney JB, Starosta-rubinstein S, Markel DS, Berent S, Giordani B, Ehrenkaufer R, Jewett D, PET scan investigations of Huntington's disease: cerebral metabolic correlates of neurological features and functional decline Ann Neurol. 1986;20:296303.

116. Antonini A, Leenders KL, Spiegel R, Meier D, Vontobel P, Weigell-Weber M, et al. Striatal glucose metabolism and dopamine D2 receptor binding in asymptomatic gene carriers and patients with Huntington's disease. Brain. 1996;119(Pt 6):2085-95.

117. López-Mora DA, Camacho V, Pérez-Pérez J, Martínez-Horta S, Fernández A, Sampedro F, et al. Striatal hypometabolism in premanifest and manifest Huntington's disease patients. Eur J Nucl Med Mol Imaging. 2016;43(12):2183-9.

118. Ciarmiello A, Cannella M, Lastoria S, Simonelli M, Frati L, Rubinsztein DC, et al. Brain white-matter volume loss and glucose hypometabolism precede the clinical symptoms of Huntington's disease. J Nucl Med. 2006;47(2):215-22.

119.• Tang CC, Feigin A, Ma Y, Habeck C, Paulsen JS, Leenders KL, et al. Metabolic network as a progression biomarker of premanifest Huntington's disease. J Clin Invest. 2013;123(9): 4076-88 In this study, 12 premanifest HD mutation carriers were scanned with $[18 \mathrm{~F}]-$-fluorodeoxyglucose PET to measure cerebral metabolic activity at baseline and again at 1.5, 4, and 7 years. In the premanifest cohort, network analysis disclosed a significant spatial covariance pattern characterized by progressive changes in striato-thalamic and cortical metabolic activity. In these subjects, network activity increased linearly over 7 years and was not influenced by intercurrent phenoconversion.

120. Berent S, Giordani B, Lehtinen S, Markel D, Penney JB, Buchtel $\mathrm{HA}$, et al. Positron emission tomographic scan investigations of Huntington's disease: cerebral metabolic correlates of cognitive function. Ann Neurol. 1988;23:541-6.

121. Ciarmiello A, Giovacchini G, Orobello S, Bruselli L, Elifani F, Squitieri F. 18F-FDG PET uptake in the pre-Huntington disease caudate affects the time-to-onset independently of CAG expansion size. Eur J Nucl Med Mol Imaging. 2012;39(6):1030-6.

122. Cui R, You H, Niu N, Li F. Interesting image FDG PET brain scan demonstrated glucose hypometabolism of bilateral caudate nuclei and putamina in a patient with chorea-acanthocytosis. Clin Nucl Med. 2015;40(12):979-80. https://doi.org/10.1097/RLU. 0000000000000968 .

123. Brockmann K, Reimold M, Globas C, Hauser TK, Walter U, Machulla HJ, et al. PET and MRI reveal early evidence of neurodegeneration in spinocerebellar ataxia type 17 . J Nucl Med. 2012;53(7):1074-81. https://doi.org/10.2967/jnumed.111. 101543.

124. Hermann W, Barthel H, Hesse S, Grahmann F, Kühn HJ, Wagner A, Villmann T. Comparison of clinical types of Wilson's disease and glucose metabolism in extrapyramidal motor brain regions. $\mathrm{J}$ Neurol 2002;249(7):896-901.
125. Hermann W, Barthel H, Hesse S, Grahmann F, Kühn HJ, Wagner A, et al. Comparison of clinical types of Wilson's disease and glucose metabolism in extrapyramidal motor brain regions. $\mathrm{J}$ Neurol. 2002;249(7):896-901.

126. Sundén-Cullberg J, Tedroff J, Aquilonius SM. Reversible chorea in primary antiphospholipid syndrome. Mov Disord. 1998;13(1): 147-9.

127. Huang HC, Wu YC, Shih LY, Lo WC, Tsai CH, Shyu WC. Reversible abnormal functional neuroimaging presentations in polycythemia vera with chorea. J Neurol. 2011;258(11):2054-7.

128. Weindl A, Kuwert T, Leenders KL, Poremba M, GräFin von Einsiedel H, Antonini A, et al. Increased striatal glucose consumption in sydenham's chorea. Mov Disord. 1993;8(4):437-44.

129. Ginovart N, Lundin A, Farde L, Halldin C, Backman L, Swahn $\mathrm{CG}$, et al. PET study of the pre- and post-synaptic dopaminergic markers for the neurodegenerative process in Huntington's disease. Brain. 1997;120(Pt 3):503-14.

130. Turjanski N, Weeks R, Dolan R, Harding AE, Brooks DJ. Striatal D1 and D2 receptor binding in patients with Huntington's disease and other choreas. A PET study. Brain. 1995;118(Pt 3):689-96.

131. Andrews TC, Weeks RA, Turjanski N, Gunn RN, Watkins LH, Sahakian B, et al. Huntington's disease progression. PET and clinical observations. Brain. 1999;122:2353-63.

132. Pavese N, Andrews TC, Brooks DJ, Ho AK, Rosser AE, Barker RA, et al. Progressive striatal and cortical dopamine receptor dysfunction in Huntington's disease: a pet study. Brain. 2003;126(5): $1127-35$.

133. van Oostrom JCH, Maguire RP, Verschuuren-Bemelmans CC, Veenma-van der Duin L, Pruim J, Roos RAC, et al. Striatal dopamine D2 receptors, metabolism, and volume in preclinical Huntington disease. Neurology. 2005;65(6):941-3.

134. Pavese N, Politis M, Tai YF, Barker RA, Tabrizi SJ, Mason SL, et al. Cortical dopamine dysfunction in symptomatic and premanifest Huntington's disease gene carriers. Neurobiol Dis. 2010;37(2):356-61.

135. Esmaeilzadeh M, Farde L, Karlsson P, Varrone A, Halldin C, Waters $\mathrm{S}$, et al. Extrastriatal dopamine $\mathrm{D}(2)$ receptor binding in Huntington's disease. Hum Brain Mapp. 2011;32(10):1626-36.

136. Bohnen NI, Koeppe RA, Meyer P, Ficaro E, Wernette K, Kilbourn $\mathrm{MR}$, et al. Decreased striatal monoaminergic terminals in Huntington disease. Neurology. 2000;54(9):1753-9.

137. Kleiman RJ, Kimmel LH, Bove SE, Lanz TA, Harms JF, Romegialli A, et al. Chronic suppression of phosphodiesterase $10 \mathrm{~A}$ alters striatal expression of genes responsible for neurotransmitter synthesis, neurotransmission, and signaling pathways implicated in Huntington's disease. J Pharmacol Exp Ther. 2011;336(1):64-76.

138. Wilson LS, Brandon NJ. Emerging biology of PDE10A. Curr Pharm Des. 2015;21:378-88.

139. Coskran TM, Morton D, Menniti FS, Adamowicz WO, Kleiman RJ, Ryan AM, et al. Immunohistochemical localization of phosphodiesterase $10 \mathrm{~A}$ in multiple mammalian species. J Histochem Cytochem. 2006;54(11):1205-13.

140.• Beaumont V, Zhong S, Lin H, Xu W, Bradaia A, Steidl E, et al. Phosphodiesterase 10A inhibition improves cortico-basal ganglia function in Huntington's disease models. Neuron. 2016;92(6): 1220-37 An important preclinical milestones demonstrating the benefit of pharmacologic PDE10 inhibition to acutely correct basal ganglia circuitry deficits in Huntington's disease models.

141. Niccolini F, Pagano G, Fusar-Poli P, Wood A, Mrzljak L, Sampaio C, Politis M Striatal molecular alterations in HD gene carriers: a systematic review and meta-analysis of PET studies. J Neurol Neurosurg Psychiatry. 2017;jnnp-2017-316633. A relevant systematic review and meta-analysis of PET studies in HD. 
142. Ahmad R, Bourgeois S, Postnov A, Schmidt ME, Bormans G, Van Laere K, et al. PET imaging shows loss of striatal PDE10A in patients with Huntington disease. Neurology. 2014;82(3):27981.

143. Russell DS, Barret O, Jennings DL, Friedman JH, Tamagnan GD, Thomae D, et al. The phosphodiesterase 10 positron emission tomography tracer, [18 F]MNI-659, as a novel biomarker for early Huntington disease. JAMA Neurol. 2014;71(12):1520-28. https:// doi.org/10.1001/jamaneurol.2014.1954.

144. Russell DS, Jennings DL, Barret O, Tamagnan GD, Carroll VM, Caille F, et al. Change in PDE10 across early Huntington disease assessed by [18F]MNI-659 and PET imaging. Neurology. 2016;86(8):748-54.

145.• Niccolini F, Haider S, Reis Marques T, Muhlert N, Tziortzi AC, Searle GE, et al. Altered PDE10A expression detectable early before symptomatic onset in Huntington's disease. Brain. 138(10):3016-29, 2015 This article is the most recent application of PDE10A molecular imaging in HD mutation carriers. It showed reduced PD10A availabilities in the premanifest phase of HD.

146. Fazio P, Bronzova J, Nag S, Warner J, Landwehrmeyer B, Halldin C, Mrzljak L. Imaging of phosphodiesterase 10 A (PDE10A) enzyme levels in the living human brain of Huntington' s disease gene expansion carriers and healthy controls with positron emission tomography. [abstract] in Mov Disord, 2017;1-2.

147. Varrone A, Fazio P, Fitzer-Attas C, Mrzljak L, Martisson S, Landwehrmeyer GB, Bronzova J, Al-Tawil N, Halldin C, Sampaio C. Positron emission tomography imaging of phosphodiesterase 10 A enzyme and dopamine D2 receptor in Huntington's disease gene expansion carriers. J Neurol Neurosurg Psychiatry. 2014;85(Suppl 1).

148. Pagano G, Niccolini F, Politis M. Current status of PET imaging in Huntington's disease. Eur J Nucl Med Mol Imaging 2016;43(6): 1171-82. https://doi.org/10.1007/s00259-016-3324-6.

149. Ooms M, Rietjens R, Rangarajan JR, Vunckx K, Valdeolivas S, Maes F, et al. Early decrease of type 1 cannabinoid receptor binding and phosphodiesterase 10a activity in vivo in R6/2 Huntington mice. Neurobiol Aging. 2014;35(12):2858-69.

150. Casteels C, Vandeputte C, Rangarajan JR, Dresselaers T, Riess O, Bormans G, Maes F, Himmelreich U, Nguyen H, Van Laere K. Metabolic and type 1 cannabinoid receptor imaging of a transgenic rat model in the early phase of Huntington disease. Exp Neurol 2011 229(2):440-449.

151. Van Laere K, Casteels C, Dhollander I, Goffin K, Grachev I, Bormans $\mathrm{G}$, et al. Widespread decrease of type 1 cannabinoid receptor availability in Huntington disease in vivo. J Nucl Med. 2010;51(9):1413-7.

152. Miniarikova J, Zanella I, Huseinovic A, van der Zon T, Hanemaaijer E, Martier R, et al. Design, characterization, and lead selection of therapeutic miRNAs targeting huntingtin for development of gene therapy for Huntington's disease. Mol Ther Nucleic Acids. 2016;5(September 2015):e297.

153. Mestre TA, Sampaio C. Huntington disease: linking pathogenesis to the development of experimental therapeutics. Curr Neurol Neurosci Rep. 2017;17(2). 